\title{
Lifting of Short Selling Constraints and Accounting Policy Options-Empirical Data from Asset Impairment Provision
}

\author{
Zijin Li \\ School of management, Jinan University, Guangzhou, China \\ Email: 17817313961@163.com
}

How to cite this paper: Li, Z.J. (2018) Lifting of Short Selling Constraints and Accounting Policy Options-Empirical Data from Asset Impairment Provision. Modern Economy, 9, 1776-1791.

https://doi.org/10.4236/me.2018.911112

Received: October 22, 2018

Accepted: November 12, 2018

Published: November 15, 2018

Copyright $\odot 2018$ by author and Scientific Research Publishing Inc. This work is licensed under the Creative Commons Attribution International License (CC BY 4.0).

http://creativecommons.org/licenses/by/4.0/

\section{(c) (i) Open Access}

\begin{abstract}
Based on 2008-2016 years' A-Share Listed Companies in China, using the capital market to lift the short selling constraints, this paper investigates its impact on the company's provision for asset impairment. The study found that the lifting of short selling constraints policy led to a significant decrease in the asset impairment provision ratio. And the significance of the company's provision for reducing the amount of assets that can be reversed is higher than the provision for impairment of non-reversible assets. The article extends the research framework of economic consequences of lifting short selling constraints, and supplements the literature on the factors that affect the company's provision for asset impairment.
\end{abstract}

\section{Keywords}

Lifting of Short Selling Constraints, Earnings Management, Supervision, Impairment of Assets

\section{Introduction}

China's capital market has been loosening stock short selling controls since March 2010, and qualified investors can short-sell transactions on stocks that enter the short-selling list. This is an important institutional reform that has achieved breakthrough development in China's A-share market, ending the history of China's stock "unilateral market" for more than 20 years. The relaxation of the short-selling control policy is continuously promoted in the manner of promotion after the pilot and the gradual expansion of the underlying stock. In the initial stage of the policy implementation, the short-selling stocks identified by the Shanghai and Shenzhen Stock Exchanges were the constituents of the SSE 
50 Index and the Shenzhen Stock Exchange, with a total of 90 stocks. With the implementation of the short-selling business, by December 2016, the number of short-selling stocks in the Shanghai and Shenzhen stock markets had increased to 950 . The amount of securities sold from less than 1.2 billion yuan in 2010, has exceeded 61 billion yuan in 2016. The rapid development of the securities lending business in China makes it particularly important to recognize the impact of the short selling mechanism on the company's financial and accounting behavior.

Judging from the existing literature, Chen Huili and Liu Feng [1], Fang et al. [2] and other studies have shown that the post-mortem price discovery function of short selling mechanism can be used as an ex ante constraint mechanism to limit management. The layer of opportunistic behavior significantly reduces the company's earnings management level; Li Zengquan [3], Riedl [4], Luo Jinhui et al. [5] and other research found that there are a variety of earnings management incentives such as avoiding losses, "big bathing", and smoothing profits in the asset impairment provision of listed companies. Then, can the relaxation of short selling control affect the accrual behavior of its asset impairment by reducing the company's earnings management level? Therefore, based on the principal-agent theory, this paper empirically tests the loose short-selling control policy on the listed company's assets minus. The value is prepared to account for the impact of the act and further examine whether this effect will vary if the impairment of the returnable assets and the non-returnable asset impairment are differentiated.

The marginal contribution of this paper is: First, expand the research perspective of relaxed short selling control. This paper takes the listed company's provision for asset impairment as an entry point, and analyzes and tests how the short selling mechanism affects the company's accounting policy choices. The article links the innovation of the stock trading system with the company's important financial activities, and expands the framework of the short-selling mechanism for the company's financial behavior research. Second, it supplements the research literature on asset impairment. Most of the literature on asset impairments examines the motives for asset impairments from the perspective of earnings management, with only a small amount of research conducting research from the macroeconomic level. The research in this paper supplements the literature on the impact of capital market factors on asset impairment.

The remaining chapters of this paper are arranged as follows. The second chapter is literature review and research hypothesis, the third chapter is research design, the fourth chapter is analysis of empirical results, and the fifth chapter is conclusion.

\section{Literature Review and Research Hypothesis}

\subsection{Related Research on Short Selling Mechanism}

Domestic and foreign research on short-selling controls or loose short-selling 
controls has focused on its impact on stock price or pricing efficiency. Miller [6] pointed out that short-selling restrictions make negative news unable to integrate into stock prices in time, resulting in overvalued stock prices. After loosening short-selling controls, the speed of negative information into stock prices has increased significantly, thus improving stock price information discovery and market efficiency [7]. Existing related research basically supports the above theory. Bris et al. [8] studied how the short-selling regulation in 46 countries (regions) affects the effectiveness of capital markets from 1990 to 2001, and finds that they can be sold in short-selling markets compared to markets that are not short-sellable. Karpoff and Lou [9] found that in the US capital market that can be sold short, bad information will be discovered in time, and the stock price can be quickly corrected through short selling. Chang et al. [10] found that the market would overestimate stocks with short-selling controls, and the price of underlying stocks would fall after loosening short-selling controls. Li Ke et al. [11] found that short-selling restrictions made stock prices overvalued, and short-selling transactions could correct overvalued stock prices and increase market pricing efficiency. Li Zhisheng et al. [12] found that the implementation of the margin financing system significantly improved the price discovery function of China's stock market, and the pricing efficiency of the underlying stocks has been significantly improved. However, some documents [13] [14] believe that due to different policy environments, market conditions and stages of development, after the relaxation of short selling control, the pricing efficiency of the market will not change significantly, and under certain circumstances, market fluctuations may be increased due to behaviors such as leveraged trading.

Recent research on relaxed short-selling controls has extended the impact of short-selling transactions on the market to the impact of short-selling transactions on the company's internal behavior. Massa et al. [15] found that short selling offers an external mechanism to effectively monitor corporate behavior. Fang et al. [2] found that the post-mortem price discovery function of short selling mechanism can be used as a pre-constraining mechanism to limit management's opportunistic behavior. Li and Zhang [16] examined the impact of loose short selling controls on management's earnings forecasting and information disclosure behavior. The study found that after the short selling restrictions are reduced, the management's forecasting accuracy will be reduced, and the disclosure of negative information will use a more vague language. Grullon et al. [17] studied the impact of loose short selling controls on corporate investment and found that capital investment in short-selling companies was significantly reduced. Chen Huili and Liu Feng [1] found that accrued earnings management and real earnings management of short-selling companies were significantly reduced, indicating that short-selling mechanisms can play an external role in China's capital market and inhibit corporate opportunistic behavior. There are also domestic studies find that loose short selling controls can inhibit the "short-selling" behavior of major shareholders [18] and increase the company's cash value [19]. 


\subsection{Related Research on Asset Impairment}

Watts and Zimmerman [20] analyzed the economic motives of managers' choice of accounting policies from the perspective of contract cost, and proposed the famous "three major motivation hypotheses", namely dividend plan assumptions, debt contract assumptions and political costs assumptions. Since the provision of asset impairment provision has always been the focus of attention in the accounting theory and practice circles in China, the company has a large autonomy in the provision of asset impairment provision. Therefore, this paper mainly selects the asset impairment as the accounting policy to inspect.

Foreign studies on asset impairment mainly focus on two aspects: market reaction and market incentives for asset impairment. The study found that the provision of asset impairments led to negative market reactions, such as lower stock returns, falling stock prices, and lower corporate economic value [21] [22] [23]; The factors affecting the company's asset impairment provision mainly include economic factors and earnings management factors. For example, Loh and Tan [24] found that economic factors such as industry attributes, historical performance, and GDP growth rate will significantly affect the accrual behavior of listed companies' asset impairment provision; Elliott and Shaw [25], Zucca and Campbell [26], Riedl [4], etc. confirmed that there are various incentives for earnings management in the listed company's asset impairment provision, such as avoiding losses, "big cleansing", and smoothing profits.

Domestic research on asset impairment is mainly about the motivation for accruing asset impairment, and the research conclusions are similar to those in foreign countries. For example, Li Zengquan [3], Zhao Chunguang [27], Luo Jinhui, etc. [5] found that the listed company's asset impairment provision generally has a surplus of avoiding losses, "big bathing" and smoothing profits. However, in addition to economic factors and earnings management factors, there are still studies in China that indicate that the robustness factor will also affect the provision of asset impairment [28]. In 2006, the Ministry of Finance promulgated a new "Enterprise Accounting Standards", which has aroused widespread concern. The standard requires that long-term asset impairment provisions cannot be reversed once they are accrued. Therefore, some articles have begun to focus on long-term asset impairment and the company's earnings management behavior [29] [30] [31], and in recent years some articles have begun to pay attention to management characteristics and the choice of asset impairment policy [32] [33] [34].

In summary, the research on loose short selling has extended from the impact of short selling to the market to the impact of short selling on the company's internal behavior. However, asset impairment as one of the company's important accounting policies has not received attention, so this paper is based on the earnings management factor to examine the impact of loose short selling controls on the company's asset impairment claims.

The core of the principal-agent theory is to solve the agency problem between 
the principal and the agent. Under the condition that the ownership structure is highly dispersed, the separation of ownership and management rights creates the first type of agency problem between shareholders and management [35]. Research on loose short selling controls shows that short selling offers an external mechanism that effectively monitors corporate behavior [15], which can alleviate agency problems and reduce agency costs. The post-mortem price discovery function of the short selling mechanism can be used as an ex ante constraint mechanism to limit the opportunistic behavior of management and significantly reduce the company's earnings management level [1] [2]. The research on the motive of asset impairment accusation shows that listed companies generally have a variety of earnings management motives to avoid losses, "bigbathing" and smooth profits in asset impairment provision [3] [4] [5]. Based on the above analysis, we believe that the relaxation of short selling regulations can reduce the company's earnings management level by reducing the company's earnings management level. So, we put forward the first hypothesis of this paper:

H1: After relaxing short selling control, the company reduced the proportion of provision for asset impairment.

In 2006, the Ministry of Finance promulgated a new "Accounting Standards for Business Enterprises", which requires that long-term asset impairment provisions cannot be reversed once they are accrued. Some studies have found that after the promulgation of the standard, listed companies are more cautious about the provision for long-term asset impairment, and the amount has decreased [29]; some studies have found that listed companies accumulate short-term after the implementation of the new standard. The earnings management incentive for asset impairment provision is stronger than the long-term asset impairment provision [30]. Based on the above analysis, we believe that in the case of distinguishing the impairment of the convertible assets and the impairment of the non-returnable assets, the company will reduce the level of significance of the provision for impairment of the assets that can be reversed after the short selling control is higher than the non-returnable assets. Based on this, we propose the second hypothesis of this paper:

$\mathrm{H} 2$ : After relaxing short selling control, the significance of the company will reduce the provision for impairment of assets that can be reversed is higher than the provision for impairment of non-returnable assets.

\section{Research Design}

\subsection{Model Setting and Research Variables}

Since the quasi-natural experiment of relaxed short selling is gradually carried out at different points in time, this paper draws on the model research design of Bertrand and Mullainathan [36] and Chen et al. [37] to test the relaxation of short selling control to the company. A company that is not short-sellable is used as a control group in a given year.

The test model for Hypothesis 1 is designed as follows: 


$$
\begin{aligned}
\mathrm{WD}_{i, t} & =\beta_{0}+\beta_{1} \text { Short }_{i, t}+\beta_{2} \text { Roa }_{i, t}+\beta_{3} \text { Growth }_{i, t}+\beta_{4} \operatorname{Ind}_{\Delta} \operatorname{Roa}_{i, t} \\
& +\beta_{5} \operatorname{IndGrowth~}_{i, t}+\beta_{6} \text { Mshare }_{i, t}+\beta_{7} \operatorname{Lev}_{i, t}+\beta_{8} \operatorname{Size}_{i, t} \\
& +\beta_{9} \mathrm{KS}_{i, t}+\beta_{10} \mathrm{PH}_{i, t}+\beta_{11} \mathrm{BG}_{i, t}+\beta_{12} \mathrm{NK}_{i, t}+\beta_{13} \mathrm{WL}_{i, t} \\
& +\beta_{14} \mathrm{PG}_{i, t}+\beta_{15} \log (\mathrm{MV})_{i, t}+\beta_{16} \text { Turnover }_{i, t}+\beta_{17} \text { Volatility }_{i, t} \\
& +\beta_{18} \mathrm{Age}_{i, t}+\alpha_{t}+\alpha_{i}+\varepsilon_{i, t}
\end{aligned}
$$

Asset Devaluation (WD): In order to test our hypothesis, we use the existing literature [29] [34] to measure the proportion of assets depreciation, that is, (the increase in current asset impairment provision-the current asset impairment reserve is reversed or resold)/the beginning of the total assets. CWD and LWD represent the ratio of the reversible asset impairment provision and the non-returnable asset impairment provision to the total assets at the beginning of the period, respectively. Since the company's provision for asset impairment provision in the current period is usually small, the values of WD, CWD and LWD are expressed as a percentage.

Whether it can be sold short (Short): Drawing on the existing literature [19] [38], short is a dummy variable. If a company can sell short in a certain year of the sample interval, the variable takes 1 ; otherwise it takes 0.If a company enters the short-selling list in 2011, the value of 2011-2016 is 1, and the value of 2007-2010 is 0; for companies that have not entered the short-selling list, the variable has a value of 0 .

The rest of the control variables are defined in the variable definition as shown in Table 1.

\subsection{Sample Selection and Data Sources}

The data in this paper is derived from the CSMAR database and the Wind database. The research sample is owned by the A-share listed companies of the Shanghai and Shenzhen Stock Exchanges. Considering the data limitations required by the model and the time to relax short-selling control, the sample period of this paper is determined as 2008-2016, and the data is screened according to the following criteria: 1) Excluding the special nature of the financial industry, the financial industry companies are excluded. 2) Excluding samples with missing relevant variables; 3) Excluding samples for special treatment (ST). After the above screening process, 17,122 samples were finally obtained, of which 3291 were short-selling companies. In order to alleviate the influence of outliers, in this regression analysis, all continuous variables were subjected to extreme processing (Winsorize) at the $1 \%$ and $99 \%$ levels.

China's securities market can sell short-selling stocks mainly for the following six adjustments: the first time is March 31, 2010, the stocks of the Shanghai Stock Exchange are all constituents of the SSE 50 Index, and the Shenzhen Stock Exchange is all 40 of the Shenzhen Index. The constituent stocks have a total of 90 stocks; the second time is December 5, 2011, the stocks under the Shanghai Stock Exchange are expanded to all constituents of the SSE 180 Index, and the stocks under the Shenzhen Stock Exchange are expanded to 98 constituents in 
the Shenzhen 100 Index; The third time is January 31, 2013, the number of stocks that can be sold in Shanghai and Shenzhen stocks increased to 500; the fourth time is September 16, 2013, the number of short-selling stocks in Shanghai and Shenzhen stocks increased from 500 up to 700; the fifth time is September 22, 2014, the number of short-selling stocks in Shanghai and Shenzhen stocks increased to 900; the sixth is the number of stocks that can be sold in Shanghai and Shenzhen add another 50 on December 12, 2016, a total of 950. Table 2 shows the distribution of short-selling stocks in the sample study interval.

Table 1. Variable definition.

\begin{tabular}{|c|c|}
\hline Variable name & Variable definitions \\
\hline$W D$ & $\begin{array}{l}\text { Impairment of assets equals (increase in current asset impairment } \\
\text { provision-current asset impairment provision reversed or resold)/total } \\
\text { assets at the beginning of the period }\end{array}$ \\
\hline Short & $\begin{array}{l}\text { Is it a } 0 \text { - } 1 \text { variable for short selling securities, if the company can sell } \\
\text { short in a certain year, take } 1 \text {; otherwise, take } 0\end{array}$ \\
\hline Roa & Company profitability, equal to net profit/total assets at the end of the period \\
\hline Growth & The growth of the company is equal to the growth rate of the main business income \\
\hline Ind $\Delta$ Roa & $\begin{array}{l}\text { The median of the current industry Roa minus the median of the previous industry } \\
\text { Roa }\end{array}$ \\
\hline IndGrowth & The median of the company's industry Growth \\
\hline Mshare & $\begin{array}{l}\text { When the management holds the company's shares, the value of Mshare is } 1 \text {, } \\
\text { otherwise it is } 0 \text {. }\end{array}$ \\
\hline $\mathrm{LeV}$ & $\begin{array}{l}\text { The company's debt level is equal to the total liabilities at the end of the } \\
\text { period/total assets at the end of the period }\end{array}$ \\
\hline Size & $\begin{array}{l}\text { The size of the company is equal to the natural logarithm of the total assets at the } \\
\text { end of the year }\end{array}$ \\
\hline$K S$ & $\begin{array}{l}\text { When the company's current ROE } t \text { (equal to the current net profit divided by the } \\
\text { average balance of the owner's equity at the beginning of the period) is negative, the } \\
\text { KS takes the value } 1 \text {, otherwise it is } 0 \text {. }\end{array}$ \\
\hline PH & $\begin{array}{l}\text { When the company's ROE exceeds the } 3 / 4 \text { quantile of the ROE of all sample } \\
\text { companies, and the values of KS, NK, WL, PG and BG are } 0 \text {, the PH value is } 1 \text {, } \\
\text { otherwise it is } 0 \text {. }\end{array}$ \\
\hline$B G$ & $\begin{array}{l}\text { When the company changes the chairman or general manager in the current period, } \\
\text { and the values of KS, NK, WL and PG are all } 0 \text {, the value of BG is } 1 \text {, otherwise it is } \\
0 \text {. }\end{array}$ \\
\hline$N K$ & When ROEt $-1<0$ and ROEt $>0$, NK takes a value of 1 , otherwise it is 0 . \\
\hline$W L$ & When ROEt $\in[0,0.02]$ and $\mathrm{NK}=0$, WL takes the value 1 , otherwise it is 0 . \\
\hline$P G$ & When ROEt $\in[0.06,0.08]$ and $\mathrm{NK}=0, \mathrm{PG}$ takes the value 1 , otherwise it is 0 . \\
\hline $\log (M V)$ & The natural logarithm of the market value of the enterprise's circulation \\
\hline Turnover & Annual average of stock turnover \\
\hline Volatility & $\begin{array}{l}\text { Stock volatility is equal to the standard deviation of the company's stock daily } \\
\text { return rate to the market daily return regression residual term }\end{array}$ \\
\hline Age & $\begin{array}{l}\text { The age at which the company is listed is defined as "the natural logarithm of } \\
\text { (the number of years of listing }+1 \text { )" }\end{array}$ \\
\hline$\alpha_{t}$ & Annual dummy variable, controlling annual fixed effects \\
\hline$\alpha_{i}$ & Company dummy variable, controlling company fixed effect \\
\hline
\end{tabular}


Table 2. Short saleable stock distribution.

\begin{tabular}{cccc}
\hline Year & $\begin{array}{c}\text { Number of } \\
\text { samples }\end{array}$ & The proportion (\%) & $\begin{array}{c}\text { The number of stock } \\
\text { samples that can be sold short }\end{array}$ \\
\hline 2008 & 1171 & 6.84 & 0 \\
2009 & 1237 & 7.22 & 0 \\
2010 & 1378 & 8.05 & 48 \\
2011 & 1783 & 10.41 & 156 \\
2012 & 2119 & 12.38 & 167 \\
2013 & 2222 & 12.98 & 569 \\
2014 & 2237 & 13.07 & 750 \\
2015 & 2366 & 13.82 & 754 \\
2016 & 2609 & 15.24 & 847 \\
\hline
\end{tabular}

Data sources: The data in this table is derived from the CSMAR database and the Wind database.

\subsection{Descriptive Statistics of Variables}

Table 3 lists the descriptive statistics for the variables. It can be seen that the provision ratio (WD) of listed companies' assets impairment provision is $0.2 \%$ on average, the median is 0 , and the standard error is 0.773 , indicating that the provision ratio of asset impairment provision exists big difference between different listed companies. On average, about $19.2 \%$ of the sample size is short-sellable. Descriptive statistics for the remaining variables are shown in Table 3.

\section{Analysis of Empirical Results}

\subsection{Regression Results}

Table 4 provides the test results for Hypothesis 1.

The results in Table 4 show that the Short coefficient is -0.06 after controlling other variables and is significant at the $1 \%$ level. In other words, after controlling for other factors affecting the proportion of asset impairment provision, the implementation of the loose short-selling control policy has significantly reduced the company's asset impairment provision ratio, which is consistent with the expectation of Hypothesis 1.

In the control variables, from the internal factors of corporate governance, the company size and management shareholdings are significantly positively correlated with the asset impairment provision ratio, that is, companies with large scale or management shares will make more provision for asset impairment. The company's total return on assets is significantly negatively correlated with the proportion of assets impairment provision, that is, the proportion of assets impairment provision of companies with high total return on assets is low. At the same time, there is a significant relationship between the variables $\mathrm{KS}, \mathrm{PH}, \mathrm{BG}$, $\mathrm{NK}$, WL used to control earnings management factors and the proportion of asset impairment provision. From the control variables related to Short, the natural 
logarithm of the company's market capitalization is significantly positively correlated with the asset impairment provision. The company's listing age is significantly negatively correlated with the asset impairment provision.

Table 5 provides the test results for Hypothesis 2. In the test hypothesis 2, referring to the existing literature (Wei Chunyan and Chen Lei, 2015), the asset impairment is divided into the convertible part (CWD) and the non-returnable part (LWD) according to the details of the impairment items disclosed in the notes to the financial statements. Specifically, the reversible part includes accounts receivable, inventory, consumable biological assets, deferred income tax assets, financial lease unguaranteed residual value, amortized cost financial assets, entrusted loans, debt assets and debt instruments available for sale, etc.; the non-returnable portion is mainly for impairment of fixed assets and intangible assets. Column (1) in the table below reports the test results when the dependent variable is the reversible asset impairment, and column (2) reports the test result when the dependent variable is the non-returnable asset impairment.

Table 3. Descriptive statistics.

\begin{tabular}{|c|c|c|c|c|c|c|}
\hline Variable & Sample size & Mean & $\begin{array}{c}\text { Standard } \\
\text { error }\end{array}$ & $\begin{array}{c}\text { First } \\
\text { quantile }\end{array}$ & Median & $\begin{array}{c}\text { Third } \\
\text { quantile }\end{array}$ \\
\hline$W D$ & 17122 & 0.174 & 0.773 & 0 & 0 & 0.231 \\
\hline$C W D$ & 17122 & 0.156 & 0.681 & 0 & 0 & 0.211 \\
\hline$L W D$ & 17122 & 0.014 & 0.156 & 0 & 0 & 0 \\
\hline Short & 17122 & 0.192 & 0.394 & 0 & 0 & 0 \\
\hline Roa & 17122 & 0.039 & 0.050 & 0.014 & 0.035 & 0.064 \\
\hline Growth & 17122 & 0.458 & 1.355 & -0.039 & 0.134 & 0.438 \\
\hline Ind $\Delta$ Roa & 17122 & -0.001 & 0.008 & -0.004 & 0 & 0.004 \\
\hline IndGrowth & 17122 & 0.189 & 0.254 & 0.086 & 0.120 & 0.207 \\
\hline Mshare & 17122 & 0.654 & 0.476 & 0 & 1 & 1 \\
\hline $\mathrm{LeV}$ & 17122 & 0.441 & 0.212 & 0.272 & 0.440 & 0.608 \\
\hline Size & 17122 & 21.984 & 1.236 & 21.084 & 21.808 & 22.690 \\
\hline$K S$ & 17122 & 0.078 & 0.268 & 0 & 0 & 0 \\
\hline$P H$ & 17122 & 0.184 & 0.388 & 0 & 0 & 0 \\
\hline$B G$ & 17122 & 0.147 & 0.354 & 0 & 0 & 0 \\
\hline$N K$ & 17122 & 0.061 & 0.240 & 0 & 0 & 0 \\
\hline$W L$ & 17122 & 0.091 & 0.288 & 0 & 0 & 0 \\
\hline$P G$ & 17122 & 0.113 & 0.317 & 0 & 0 & 0 \\
\hline $\log (M V)$ & 17122 & 22.055 & 1.065 & 21.321 & 22.042 & 22.727 \\
\hline Turnover & 17122 & 0.029 & 0.022 & 0.014 & 0.023 & 0.039 \\
\hline Volatility & 17122 & 0.025 & 0.008 & 0.020 & 0.024 & 0.030 \\
\hline Age & 17122 & 2.116 & 0.771 & 1.609 & 2.303 & 2.773 \\
\hline
\end{tabular}

Data sources: The data in this table is derived from the CSMAR database and the Wind database. 
Table 4. Proportion of relaxed short selling and asset impairment.

\begin{tabular}{|c|c|c|}
\hline \multirow{2}{*}{ Variable name } & \multicolumn{2}{|c|}{$W D$} \\
\hline & Coef. & t-Stat \\
\hline Short & $-0.060^{\star * \star}$ & -2.62 \\
\hline Roa & $-3.841^{* * *}$ & -8.46 \\
\hline Growth & 0.007 & 0.96 \\
\hline Ind $\Delta$ Roa & 2.213 & 1.51 \\
\hline IndGrowth & -0.065 & -0.97 \\
\hline Mshare & $0.053^{\star *}$ & 2.05 \\
\hline LeV & -0.056 & -0.6 \\
\hline Size & $0.044^{\star}$ & 1.8 \\
\hline$K S$ & $0.290^{\star * *}$ & 6.2 \\
\hline$P H$ & $0.121^{* * *}$ & 4.73 \\
\hline$B G$ & $0.047^{* * *}$ & 2.75 \\
\hline$N K$ & $-0.140^{* * *}$ & -3.52 \\
\hline$W L$ & $-0.095^{\star * *}$ & -3.73 \\
\hline$P G$ & -0.017 & -0.98 \\
\hline $\log (M V)$ & $0.059^{* * *}$ & 3.32 \\
\hline Turnover & 0.096 & 0.18 \\
\hline Volatility & -1.515 & -0.96 \\
\hline Age & $-0.367^{\star * \star}$ & -10.56 \\
\hline Cons & -0.867 & -1.56 \\
\hline Annual fixed effect & & \\
\hline Company fixed effect & & \\
\hline $\mathrm{R}^{2}$ & & \\
\hline Sample size & & \\
\hline
\end{tabular}

Data sources: The data in this table is derived from the CSMAR database and the Wind database.

Table 5. Relaxation of short selling control and asset impairment ratio-distinguishing the impairment of convertible assets and the impairment of non-returnable assets.

\begin{tabular}{ccccc}
\hline \multirow{2}{*}{ Variable name } & \multicolumn{2}{c}{ (1) CWD } & \multicolumn{2}{c}{$(2) L W D$} \\
\cline { 2 - 5 } & Coef. & $\mathrm{t}$-Stat & Coef. & $\mathrm{t}$-Stat \\
\hline Short & $-0.043^{* *}$ & -2.14 & $-0.009^{*}$ & -1.67 \\
Roa & $-2.607^{* * *}$ & -6.86 & $-0.652^{* * *}$ & -6.98 \\
Growth & 0.007 & 1.12 & -0.001 & -0.49 \\
IndDRoa & 1.805 & 1.47 & 0.305 & 0.91 \\
IndGrowth & -0.053 & -0.86 & -0.008 & -0.63 \\
Mshare & $0.047^{* *}$ & 1.99 & 0.004 & 0.67 \\
LeV & -0.069 & -0.87 & 0.003 & 0.18 \\
\hline
\end{tabular}




\section{Continued}

\begin{tabular}{|c|c|c|c|c|}
\hline Size & 0.036 & 1.63 & $0.009^{* *}$ & 1.99 \\
\hline$K S$ & $0.326^{* * *}$ & 5.87 & $0.033^{* * *}$ & 3.45 \\
\hline$P H$ & $0.079^{* * *}$ & 3.51 & $0.024^{\star * *}$ & 4.68 \\
\hline$B G$ & $0.030^{* *}$ & 2.04 & $0.012^{\star * *}$ & 2.79 \\
\hline$N K$ & $-0.124^{* * *}$ & -3.49 & -0.011 & -1.46 \\
\hline$W L$ & $-0.056^{* *}$ & -2.51 & $-0.018^{\star * *}$ & -3.40 \\
\hline$P G$ & -0.020 & -1.29 & 0.003 & 0.75 \\
\hline $\log (M V)$ & $0.033^{* *}$ & 2.12 & $0.009^{* *}$ & 2.43 \\
\hline Turnover & 0.084 & 0.17 & -0.077 & -0.70 \\
\hline Volatility & -1.517 & -1.09 & 0.555 & 1.64 \\
\hline Age & $-0.339^{* * *}$ & -10.62 & -0.008 & -1.22 \\
\hline Cons & -0.274 & -0.56 & $-0.350^{* * *}$ & -3.19 \\
\hline Annual fixed effect & \multicolumn{2}{|c|}{ Yes } & \multicolumn{2}{|c|}{ Yes } \\
\hline Company fixed effect & \multicolumn{2}{|c|}{ Yes } & \multicolumn{2}{|c|}{ Yes } \\
\hline $\mathrm{R}^{2}$ & \multicolumn{2}{|c|}{0.11} & \multicolumn{2}{|c|}{0.04} \\
\hline Sample size & \multicolumn{2}{|c|}{17,122} & \multicolumn{2}{|c|}{17,122} \\
\hline
\end{tabular}

Data sources: The data in this table is derived from the CSMAR database and the Wind database.

The results in Table 5 show that when the dependent variable is the reversible asset impairment, the short coefficient is -0.043 and is significant at the $5 \%$ lev$\mathrm{el}$, and when the dependent variable is not convertible, the coefficient of short is -0.009 , which is only significant at the level of $10 \%$. And the coefficient of the variable short has statistically significant difference in the grouping regression. The regression result is consistent with the expectation of Hypothesis 2, that is, after relaxing the short selling control, the company will reduce the provision for impairment of assets that can be transferred back is more significant than the provision for impairment of non-returnable assets.

\subsection{Robustness Test}

\subsubsection{Using Alternative Methods to Measure Asset Impairment}

In order to verify the robustness of the research conclusions, this paper further measures the asset impairment based on the asset impairment loss confirmed in the income statement. The specific calculation method is the current asset impairment loss divided by the total assets at the beginning of the year.

The results in Table 6 show that after controlling other variables that affect asset impairment, Short's coefficient is -0.089 , and is significant at the $1 \%$ level, that is, the implementation of the relaxed short-selling control policy significantly reduces the company's asset impairment losses.. This conclusion further supports the research hypothesis of this paper.

\subsubsection{Using Alternative Methods to Measure Relaxed Short Selling} At the same time, this paper uses the margin ratio to further measure the relaxa- 
tion of short selling, and the margin ratio (S_Ratio) is calculated by the margin sales amount/circulation market value.

The results in Table 7 show that when the dependent variable is asset impairment (WD), the coefficient of S_Ratio is -1.523 and is significant at the $1 \%$ level; when the dependent variable is returnable to asset impairment (CWD), S_Ratio The coefficient is -0.943 , which is also significant at the $1 \%$ level; when the dependent variable is non-returnable to asset impairment (LWD), the coefficient of S_Ratio is -0.247 , which is only significant at the $5 \%$ level. In the second and third columns, the coefficient of the variable short has statistically significant difference in the grouping regression. This further validates the content of Hypothesis 1 and Hypothesis 2.

Table 6. Relaxation of short selling controls and asset impairment losses.

\begin{tabular}{|c|c|c|}
\hline \multirow{2}{*}{ Variable name } & \multicolumn{2}{|c|}{$W D_{1}$} \\
\hline & Coef. & t-Stat \\
\hline Short & $-0.089^{* * *}$ & -2.74 \\
\hline Roa & $-10.533^{* * *}$ & -14.45 \\
\hline Growth & 0.011 & 1.33 \\
\hline Ind $\Delta R o a$ & $4.114^{* *}$ & 2.4 \\
\hline IndGrowth & -0.028 & -0.3 \\
\hline Mshare & $0.106^{* * *}$ & 2.89 \\
\hline Lev & 0.102 & 0.68 \\
\hline Size & $-0.163^{* * *}$ & -3.92 \\
\hline$K S$ & $0.706^{* * *}$ & 9.96 \\
\hline$P H$ & $0.396^{* * *}$ & 11.6 \\
\hline$B G$ & $0.162^{* * *}$ & 7.74 \\
\hline$N K$ & $0.177^{* * *}$ & 3.4 \\
\hline$W L$ & $-0.200^{* * *}$ & -5.88 \\
\hline$P G$ & -0.014 & -0.75 \\
\hline $\log (M V)$ & $0.190^{* * *}$ & 7.32 \\
\hline Turnover & $2.480^{* * *}$ & 3.05 \\
\hline Volatility & $-4.447^{\star *}$ & -2.07 \\
\hline Age & -0.041 & -0.85 \\
\hline Cons & 0.755 & 0.87 \\
\hline Annual fixed effect & & \\
\hline Company fixed effect & & \\
\hline $\mathrm{R}^{2}$ & & \\
\hline Sample size & & \\
\hline
\end{tabular}

Data sources: The data in this table is derived from the CSMAR database and the Wind database. 
Table 7. Ratio of securities lending ratio to asset impairment.

\begin{tabular}{|c|c|c|c|c|c|c|}
\hline \multirow{2}{*}{ Variable name } & \multicolumn{2}{|c|}{ (1) $W D$} & \multicolumn{2}{|c|}{ (2) $C W D$} & \multicolumn{2}{|c|}{ (3) $L W D$} \\
\hline & Coef. & t-Stat & Coef. & $\mathrm{t}-$ Stat & Coef. & $\mathrm{t}$-Stat \\
\hline S_Ratio & $-1.523^{* * *}$ & -3.60 & $-0.943^{\star * *}$ & -2.7 & $-0.247^{\star *}$ & -2.18 \\
\hline Roa & $-3.839^{* * *}$ & -8.48 & $-2.603^{\star * *}$ & -6.85 & $-0.652^{* * *}$ & -6.99 \\
\hline Growth & 0.007 & 0.95 & 0.007 & 1.11 & -0.001 & -0.50 \\
\hline Ind $\Delta R o a$ & 2.137 & 1.46 & 1.767 & 1.44 & 0.292 & 0.87 \\
\hline IndGrowth & -0.066 & -0.97 & -0.053 & -0.87 & -0.008 & -0.63 \\
\hline Mshare & $0.051^{\star *}$ & 1.96 & $0.045^{*}$ & 1.92 & 0.003 & 0.6 \\
\hline LeV & -0.062 & -0.67 & -0.073 & -0.92 & 0.003 & 0.13 \\
\hline Size & $0.045^{*}$ & 1.85 & $0.036^{*}$ & 1.65 & $0.009^{* *}$ & 2.03 \\
\hline KS & $0.291^{* * *}$ & 6.22 & $0.237^{* * *}$ & 5.89 & $0.033^{* * *}$ & 3.47 \\
\hline$P H$ & $0.120^{* * *}$ & 4.68 & $0.079^{* * *}$ & 3.48 & $0.024^{\star \star \star}$ & 4.65 \\
\hline$B G$ & $0.045^{\star * *}$ & 2.68 & $0.029^{\star *}$ & 1.98 & $0.011^{* * *}$ & 2.74 \\
\hline$N K$ & $-0.139^{\star * *}$ & -3.48 & $-0.123^{\star * *}$ & -3.46 & -0.011 & -1.44 \\
\hline$W L$ & $-0.095^{* * *}$ & -3.73 & $-0.056^{\star *}$ & -2.51 & $-0.018^{* * *}$ & -3.4 \\
\hline$P G$ & -0.017 & -0.98 & -0.020 & -1.28 & 0.003 & 0.76 \\
\hline $\log (M V)$ & $0.055^{\star * *}$ & 3.10 & $0.030^{*}$ & 1.94 & $0.009^{* *}$ & 2.28 \\
\hline Turnover & 0.093 & 0.17 & 0.068 & 0.14 & -0.076 & -0.69 \\
\hline Volatility & -1.525 & -0.98 & -1.476 & -1.07 & 0.548 & 1.63 \\
\hline Age & $-0.360^{* * *}$ & -10.59 & $-0.334^{* * *}$ & -10.64 & -0.007 & -1.10 \\
\hline Cons & -0.805 & -1.46 & -0.223 & -0.46 & $-0.341^{\star * *}$ & -3.13 \\
\hline Annual fixed effect & \multicolumn{2}{|c|}{ Yes } & \multicolumn{2}{|c|}{ Yes } & \multicolumn{2}{|c|}{ Yes } \\
\hline $\begin{array}{l}\text { Company } \\
\text { fixed effect }\end{array}$ & \multicolumn{2}{|c|}{ Yes } & \multicolumn{2}{|c|}{ Yes } & \multicolumn{2}{|c|}{ Yes } \\
\hline $\mathrm{R}^{2}$ & \multicolumn{2}{|c|}{0.12} & \multicolumn{2}{|c|}{0.11} & \multicolumn{2}{|c|}{0.04} \\
\hline Sample size & \multicolumn{2}{|c|}{17,122} & \multicolumn{2}{|c|}{17,122} & \multicolumn{2}{|c|}{17,122} \\
\hline
\end{tabular}

Data sources: The data in this table is derived from the CSMAR database and the Wind database.

The above empirical test results can fully support the hypothesis of the article. After relaxing the short selling control, the company reduced the proportion of the provision for impairment of assets, and the significance of the company will reduce the provision for impairment of assets that can be reversed is higher than the provision for impairment of non-returnable assets. In the robustness test, the conclusion is still true after replacing the main variables.

\section{Conclusions}

Existing literature studies have shown that the post-mortem price discovery function of short selling mechanism can be used as a pre-existing constraint mechanism to limit the opportunistic behavior of management and significantly 
reduce the company's earnings management level, while there are many kinds of earnings management motives such as avoiding losses, "big bathing" and smoothing profits in the provision of asset impairment. Therefore, this paper focuses on the effect of relaxing short selling control on the accrual behavior of listed companies' asset impairment provisions, and further investigates whether this effect will be different in the case of distinguishing the reversible asset impairment and the non-returnable asset impairment.

This paper takes the listed companies in Shanghai and Shenzhen in 2008-2016 as the research samples, and examines the aforementioned problems by means of the exogenous event of loose short selling control. The research in this paper finds that after relaxing the short selling control, the company reduces the proportion of the provision for impairment of assets, and the company's reduced provision for the provision for impairment of assets can be higher than the non-returnable asset impairment provision. This also provides a basis for the relaxation of short-selling regulations to help companies reduce their earnings management, and provides an explanation for the continued expansion of short-selling targets.

The research in this paper still has some shortcomings: Since short selling transactions started late in China, the current stocks that can be sold short account for a small proportion of the overall sample. During the sample period, the sample size of stocks that can be sold short is only $19.2 \%$ of the total sample.

\section{Conflicts of Interest}

The author declares no conflicts of interest regarding the publication of this paper.

\section{References}

[1] Chen, H.L. and Liu, F. (2014) Research on the Governance Effect of Margin Financing-Based on the Perspective of Corporate Earnings Management. Accounting Research, 9, 45-52.

[2] Fang, V.W., Huang, A. and Karpoff, J. (2016) Short Selling and Earnings Management: A Controlled Experiment. Journal of Finance, 71, 1251-1294. https://doi.org/10.1111/jofi.12369

[3] Li, Z.Q. (2001) An Empirical Study on Assets Devaluation Policy of Listed Companies in China. China Accounting and Finance Research, 3, 70-113.

[4] Reidl, E.J. (2004) An Examination of Long-Lived Asset Impairments. The Accounting Review, 79, 823-852. https://doi.org/10.2308/accr.2004.79.3.823

[5] Luo, J.H., Wan, D.Z. and Li, C. (2010) Net Provision for Assets Depreciation Reserves, Earnings Management and Corporate Governance Structure-Evidence from Chinese Manufacturing Listed Companies in 2004-2008. China Accounting Review, 8, 179-200.

[6] Miller, E.M. (1977) Risk, Uncertainty and Divergence of Opinion. Journal of Finance, 32, 1151-1168. https://doi.org/10.1111/j.1540-6261.1977.tb03317.x

[7] Boehmer, E. and Wu, J. (2012) Short Selling and the Price Discovery Process. The Review of Financial Studies, 26, 287-322. https://doi.org/10.2139/ssrn.972620 
[8] Bris, A., Goetzmann, W.N. and Zhu, N. (2007) Efficiency and the Bear: Short Sales and Markets around the World. Journal of Finance, 62, 1029-1079. https://doi.org/10.1111/j.1540-6261.2007.01230.x

[9] Karpoff, J.M. and Lou, X. (2010) Short Sellers and Financial Misconduct. Journal of Finance, 65, 1879-1913. https://doi.org/10.1111/j.1540-6261.2010.01597.x

[10] Chang, E.C., Luo, Y. and Ren, J. (2014) Short-Selling, Margin-Trading, and Price Efficiency: Evidence from the Chinese Market. Journal of Banking and Finance, 48, 411-424. https://doi.org/10.1016/j.jbankfin.2013.10.002

[11] Li, K., Xu, L.B. and Zhu, W.Q. (2014) Short-Selling Restrictions and Stock Mispricing-Evidence of Margin Financing and Securities Lending System. Economic Research, 10, 165-178.

[12] Li, Z.S., Chen, C. and Lin, B.X. (2015) Does the Short Selling Mechanism Improve the Pricing Efficiency of China's Stock Market?-Based on Evidence from Natural Experiments. Economic Research, 4, 165-177.

[13] Allen, F. and Gale, D. (1991) Arbitrage, Short Sales and Financial Innovation. Econometrica, 59, 1041-1068. https://doi.org/10.2307/2938173

[14] Keim, D.B. and Madhaven, A. (1995) Anatomy of the Trading Process: Empirical Evidence on the Behavior of Institutional Traders. Journal of Financial Economics, 37, 371-398. https://doi.org/10.1016/0304-405X(94)00799-7

[15] Massa, M., Zhang, B. and Zhang, H. (2015) The Invisible Hand of Short Selling: Does Short Selling Discipline Earnings Manipulation? Review of Financial Studies, 28, 1701-1736. https://doi.org/10.1093/rfs/hhu147

[16] Li, Y. and Zhang, L. (2015) Short Selling Pressure, Stock Price Behavior, and Management Forecast Precision: Evidence from a Natural Experiment. Journal of Accounting Research, 53, 79-117. https://doi.org/10.1111/1475-679X.12068

[17] Grullon, G., Michenaud, S. and Weston, J. (2015) The Real Effects of Short-Selling Constraints. Review of Financial Studies, 28, 1737-1767. https://doi.org/10.1093/rfs/hhv013

[18] Hou, Q.C., Yan, Q.L., Su, L. and Yu, Y. (2017) Relaxation of Short Selling Control and Short Selling of Major Shareholders. Economics (Quarterly), 3, 1143-1172.

[19] Hou, Q.C., Zhao, Q.L. and Liu, Y. (2016) Relaxation of Short Selling Control and Corporate Cash Value-Quasi-Nature Experiment Based on China's Capital Market. Financial Research, 11, 112-127.

[20] Watts, R. and Zimmerman, J. (1978) Toward a Positive Theory of the Determinations of Accounting Standards. Accounting Review, 53, 112-134.

[21] Francis, J., Hanna, J.D. and Vicent, L. (1996) Causes and Effects of Discretionary Asset Write-Offs. Journal of Accounting Research, 34, 91-114. https://doi.org/10.2307/2491429

[22] Bartov, E., Lindahl, W. and Shaw, W.H. (1998) Stock Price Behavior around Announcements of Write-Offs. Review of Accounting Studies, 4, 327-346. https://doi.org/10.1023/A:1009644800963

[23] Hsieh, W.T. and Wu, T.Z. (2005) Determinants and Effects of Assets Impairment Decision in Taiwan. Taiwan Accounting Review, 6, 59-95.

[24] Loh, A.L.C. and Tan, T.H. (2002) Assets Write-Offs Managerial Incentives and Macroeconomics Factors. Abacus, 38, 134-151. https://doi.org/10.1111/1467-6281.00101

[25] Elliott, J. and Shaw, W. (1988) Write-Offs as Accounting Procedures to Manage Perceptions. Journal of Accounting Research, 26, 91-119. 
https://doi.org/10.2307/2491182

[26] Zucca, L.J. and Campbell, D.R. (1992) A Closer Look at Discretionary Write Downs of Impaired Assets. Accounting Horizons, 6, 30-41.

[27] Zhao, C.G. (2006) Asset Impairment and Earnings Management-On the Policy Implication of the Assets Impairment Guidelines. Accounting Research, 3, 11-16.

[28] Dai, B.B., Lu, Z.F. and Zhang, R. (2007) Asset Impairment: Robustness or Earnings Management. Accounting Research, 12, 35-42.

[29] Zhang, R., Lu, Z.F. and Ye, K.T. (2007) Changes in Accounting Standards and Long-Term Asset Impairment. Management World, 8, 77-84.

[30] Li, W. and Huang, W. (2011) Long-Term Asset Devaluation, Earnings Management and Value Relevance-An Empirical Study Based on the Changes of New Accounting Standards. Management Review, 23, 144-152.

[31] Zhang, J.X. and He, Y.N. (2014) The Reversibility of Asset Impairment, Management Responsibility and Management Investment Decision-An Experimental Evidence. Nankai Business Review, 17, 78-87.

[32] Wang, F.S. and Cheng, F. (2014) CFO Background Characteristics and Accounting Policy Choice from the Perspective of Management Defense-Experience Data from Asset Depreciation Accruals. Accounting Research, 12, 32-38.

[33] Chen, Y., Li, B.X. and Li, Y. (2015) Manager Characteristics, Management Defense and Long-Term Asset Impairment Policy Selection. Management Review, 27, 140-147.

[34] Wei, C.Y. and Chen, L. (2015) Altruism in the Process of Family CEO Change-Based on Asset Devaluation. Management World, 3, 137-150.

[35] Jensen, M.C. and Mecking, W.H. (1976) Theory of the Firm: Managerial Behavior, Agency Costs and Ownership Structure. Journal of Financial Economics, 3, 305-360. https://doi.org/10.1016/0304-405X(76)90026-X

[36] Bertrand, M. and Mullainathan, S. (2003) Enjoying the Quiet Life? Corporate Governance and Managerial Preferences. Journal of Political Economy, 111, 1043-1075. https://doi.org/10.1086/376950

[37] Chen, Q., Chen, X., Schipper, K., Xu, Y. and Xue, J. (2012) The Sensitivity of Corporate Cash Holdings to Corporate Governance. Review of Financial Studies, 25, 3610-3644. https://doi.org/10.1093/rfs/hhs099

[38] Zhao, Q.L., Hou, Q.C., Li, G. and Xie, Y.Z. (2015) Relaxation of Short Selling Control, Company Investment Decision and Option Value. Economic Research, 10, 76-88. 